Article

\title{
Active Citizens: Evaluation of a Community-Based Education Program
}

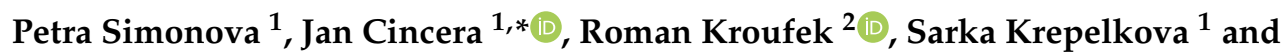 \\ Andreas Hadjichambis ${ }^{3}$
}

1 Department of Environmental Studies, Faculty of Social Studies, Masaryk University, 60200 Brno, Czech Republic; simonova.tereza@gmail.com (P.S.); sarka.krepelkova@gmail.com (S.K.)

2 Department of Preschool \& Primary Education, Faculty of Education, Jan Evangelista Purkyně University in Ústí nad Labem, 40096 Ústí nad Labem, Czech Republic; kroufek@gmail.com

3 Cyprus Center for Environmental Research and Education, Limassol 3304, Cyprus; a.chadjihambi@cytanet.com.cy

* Correspondence: honzacincera@gmail.com; Tel.: +420-549-49-3482

Received: 10 December 2018; Accepted: 24 January 2019; Published: 28 January 2019

check for updates

\begin{abstract}
This study analyses the Active Citizens program conducted in seven Czech elementary schools in 2017/2018. The data were obtained in a mixed-design research study containing pre/post experimental/control groups $(\mathrm{N}=114)$, eight focus groups with selected students $(\mathrm{N}=56)$, and group interviews with teachers $(\mathrm{N}=14)$. The mean age of the students was 13.8 years. The study focuses on the students' and the teachers' perception of the process, the program's barriers and benefits, and on the impact of the program on the students' self-efficacy and on perceived democratic school culture. The analysis revealed that while the participants felt empowered because of their experience, they started to perceive their school environment as less democratic than before the program. The program also likely influenced girls more than boys as the latter seem to have been unaffected. Finally, the implications of the findings for the practice are discussed.
\end{abstract}

Keywords: self-efficacy; participation; action competence; education for environmental citizenship

\section{Introduction}

Education for Environmental Citizenship (EEC) has become one of the newly emerging approaches in the field of education [1-4]. In the on-going project "European Network for Environmental Citizenship" it is defined as:

"the type of education which cultivates a coherent and adequate body of knowledge as well as the necessary skills, values, attitudes and competencies that an environmental citizen should be equipped with in order to be able to act and participate in society as an agent of change in the private and public sphere, on a local, national and global scale, through individual and collective actions, in the direction of solving contemporary environmental problems, preventing the creation of new environmental problems, in achieving sustainability as well as developing a healthy relationship with nature. 'Education for Environmental Citizenship' (EEC) is important to empower citizens to exercise their environmental rights and duties, as well as to identify the underlying structural causes of environmental degradation and environmental problems, develop the willingness and the competences for critical and active engagement and civic participation to address those structural causes, acting individually and collectively within democratic means and taking into account interand intra-generational justice." [5] 
According to the above definition, there are eight intended outcomes of EEC: preventing new environmental problems, contributing to solving current environmental problems, practicing environmental rights and duties, identifying structural causes of environmental degradation and problems, achieving critical and active engagement and civic participation, promoting inter- and intra-generational justice, developing a healthy relationship with nature, and achieving sustainability. These outcomes can be achieved through individual and collective actions to be applied in different spheres (private and public) and on different scales (local, national, and global).

While the distinctive features of the EEC approach, which clearly blends aspects of environmental education and education for sustainable development, are still in their inception phase, it is evident that the approach highlights the idea of active civic participation of students in decision-making processes on the community level with the aim to promote both their action competences and change in the real world.

According to Schild [6], environmental citizenship has never been at the heart of our education system and thus there is a need for explicit focus on environmental citizenship. However, the pedagogical landscape of EEC is based on some already existing pedagogical approaches.

In the area of formal education, encouraging students to promote positive change in their community has been a long-term effort. Specifically, the concept of place-based education [7-9], especially its critical interpretation [10], calls for the re-interpretation of the role of schools and their transformation from detached institutions to agents of change. Other authors have highlighted the importance of the development of students' competences for taking collective action [11,12] as a prerequisite for their future participation in civic decision-making processes.

The concept of action competence has largely been accepted and elaborated in the discourse about education for sustainable development (ESD). While multiple sets of ESD competences have been developed [13-15], we may assume that it is particularly the strategic, anticipatory, and interpersonal competences as defined by Wiek et al. [16] that form the main core of what education for environmental citizenship seeks to cultivate. Aside from the effort to include an opportunity for collective, community-based action into school curricula, active participation of students in shaping the process is considered to be another condition for promoting students' action competence [11-17]. However, regardless of its importance, not many teachers yet view this approach as their priority $[18,19]$.

The two principles of active participation and community-based action, support each other. As Gaventa and Barett [20] suggest, dealing with a specific problem plays an important role in developing students' skills, self-confidence, and motivation. According to Westheimer and Kahne [21], students need to believe that they have an opportunity and capacity to make a real change. Bearing this in mind, the process of setting up and selecting the project is crucial: unless students believe that there is a chance for them to influence the process, they may lose their motivation. However, if the selected project exceeds their abilities, they may become demotivated and their self-efficacy may drop [22,23].

Another pitfall is the effort of some teachers to avoid students' involvement in potentially political issues, which leads them to direct the students' work towards projects that are broadly acceptable but that do not reflect the real needs of their community. While this approach may offer a safer framework for the teachers, it also compromises the opportunities for developing the students' competence [23-25]. According to Boyte [24], while such non-controversial projects bring important educational benefits (e.g., personal growth, experiential learning), they may fail to develop students' skills for solving social problems.

This effort is of a special importance in the Czech Republic. According to Krajhanzl, Chabada, and Svobodova [26], while most Czech citizens support environmental protection and engage in various types of easily adopted pro-environmental behavior (e.g., recycling), their willingness to get involved in public decision-making processes on a community level is considerably low. These findings correspond with those of Petrova and Tarrow [27], who found that Central and Eastern European countries have a relatively weak capacity for collective, participative actions, which is a reflection of political apathy 
and a rise in egoistic individualism. As various surveys have repeatedly confirmed a high level of acceptance of pro-environmental attitudes among adults, children, and teachers in the Czech Republic [26,28-30] and other countries [31-36], it has become clear that not only attitudes, but also action competence, the feeling of empowerment, and self-efficacy are what need to be promoted in contemporary society [11-14,17].

Due to this situation, supporting students' motivation and competencies for promoting real change in their community should be a top priority. Unfortunately, while most Czech elementary schools are willing to introduce students to global sustainability problems, participation in local community-based projects dealing with real-life issues remains very rare. Moreover, the participative approach has been adopted in only a small number of Czech schools [37].

To overcome this gap, a new, community-based school program called "Active Citizens" has been launched in the Czech Republic.

Active Citizens (AC) is an international program managed by the British Council. Since its launch in 2009, schools from 68 countries have become involved [38]. The national coordinator, the non-governmental organization People in Need (Člověk v tísni), emphasizes the principles of community-based approach and students' involvement in solving problems in their community.

The AC program theory is based on the idea that students need to develop their intra- and interpersonal competence before they set out to promote changes in their community. To achieve this, students start with teacher-instructed, experiential learning centered around topics that are divided into three stages: (1) Me (Identity and Culture) in which students develop their intrapersonal competence and understanding of their broader cultural identity; (2) Me and You (Dialog) in which they practice their interpersonal competence (communication and cooperation skills); and (3) We Together (as Citizens) in which they focus on understanding the distinctive features of their community, the existing power structures, and the connections with a broader, global level. In these stages, students' competences are developed mainly through a set of games and discussions. After this, they proceed to planning (stage 4) together with conducting and evaluating (stage 5) their project. In 2012-2014, the program was tested in 37 schools. Participation in the program is voluntary; students form small teams and cooperate with their teachers as an after-school activity $[39,40]$.

According to the first evaluation round, the AC program helped in developing students' conceptual understanding of community and active citizenship by making these concepts less abstract and more specific to students. However, as the evaluated competencies were only vaguely defined, the impact of the program on their development remained rather arbitrary [41].

In this study, we analyze the AC program from the perspective of (a) its process, examining how the process was perceived by both the participating students and teachers, and (b) its impact on the students' perception of democratic school climate and the students' action competence, namely their belief in their capacity to promote real-world change.

In particular, we interpret the AC program within the framework of EEC. As EEC is an emerging concept, it was not originally used for framing the AC program. However, the aims of the AC program overlap with the main features of the EEC approach, especially in highlighting the importance of empowering children to be agents of change and in developing children's competence for critical and active engagement [5]. Given the absence of EEC application in schools so far, our study tries to identify how such application may be carried out and what practical issues should be taken into consideration in further modifying EEC in the future.

\section{Materials and Methods}

The study focuses on the following questions:

- What is the impact of the AC program on students' perceived capacity to conduct communitybased actions?

- What is the impact of the AC program on students' perception of democratic school climate? 
- How do students and teachers interpret their experience, specifically the process of their participation in the AC program and its benefits?

To achieve this, we used a mixed research design. The students completed a written questionnaire before (pre-test) and after (post-test) participating in the AC program. The questionnaire construction followed the usual standards for text design and development [42]. The qualitative part of the research was based on interviews with the teachers and on focus groups with the students participating in the program. Data were collected from autumn 2017 (pre-test) through spring 2018 (post-test, interviews, focus groups).

The questionnaire tested three variables:

- Self-efficacy to solve a community-based problem, specifically one's own perceived competence to conduct community-based actions. The scale was taken from Chen, Gully, and Eden [43] and modified. It was covered by five items in the questionnaire $(\alpha=0.85)$.

- Students' participation in decision-making in a community-based project, specifically how students/teachers perceived how they were able to get involved in the planning and realization of the project and how they were able to put through their own opinions. The scale was created on the basis of scales applied in Gastil and Xenos [44] and Cincera, de Boeve-Pauw, Goldman, and Simonova [45]. It was covered by five items in the questionnaire $(\alpha=0.85)$.

- Democratic school climate as students' / teachers' perception of how democratic the school climate is [46]. It was covered by five items in the questionnaire $(\alpha=0.79)$.

The experimental group of students ( $\mathrm{N}=74,29$ male, 45 female) consisted of students from seven Czech elementary schools involved in the AC program in $2017 / 2018$. The control group ( $N=40,21$ males, 19 females) consisted of students from seven schools that did not participate in the AC program and that did not participate in any similar activities or a community project, either. The students' mean age was 13.8 years. The questionnaire data were subsequently paired (pre-test and post-test) and compared separately for the experimental and the control group. The data were analyzed by t-test $(\alpha=0.05)$ that is robust enough even against data with non-normal distribution [47].

In the second part of the research, eight focus groups with selected students of the average age 14 years $(\mathrm{N}=56,25$ male, 31 female $)$ and group interviews with teachers $(\mathrm{N}=14)$ were conducted (10 females, 4 males). Each focus group included 4-8 students from one of the seven elementary schools involved in the AC program. The selection criteria were: representation of very active students as well as less active ones and making sure that students selected for the group had no problem communicating as a group. The teachers were asked to select the students according to these criteria, but the students could decide whether they wanted to participate or not. However, all of the selected students agreed to be included into a focus group. The selection criteria and number of focus groups were set according to existing recommendations [48,49].

Subsequently, interviews with the teachers involved in the AC program were conducted. The interviews and focus groups were recorded, and the data were transcribed and coded. Specifically, we applied the open-coding procedure for data segments, and then grouped the initial codes into broader thematic categories [50]. This procedure was conducted by the first author, and it was informed by a continual discussion with the second and fourth authors, who suggested some changes as needed. The initial findings were further discussed in the team of the authors. To increase the credibility of the findings, the analysis was presented to the program's national coordinator, who shared it with the teachers involved. The coordinator approved the findings and provided only minor (mostly formal) comments on some of them. After receiving this feedback, the analysis was further improved.

\section{Results}

Eight community-based projects were successfully completed within the sample. In six projects, students were involved in direct community-based action, e.g., the kind of activity where students directly tried to promote changes in their community [12]. Specifically, students cooperated in 
designing bird nests, greening their school yard, and manufacturing new benches. In two of the projects, students were involved in a kind of non-direct action, e.g., they tried to promote change in their community by influencing other people (i.e., increasing safety in crossing the streets or conducting an information campaign about recycling).

The initial (1-3) stages of the project were perceived ambiguously. Both the teachers and the students reported that the activities aiming to develop the students' competence were too long. While the students started the program motivated to change something in their community, after a few months of preparation they began to feel tired and disappointed, and the teachers had to motivate them again:

"Suddenly we started doing something that had no clearly defined aim, and the children (...) did not know much what to expect (...) and they commented that they came to play icebreakers (...) and X and I could see distrust on their part, as to how it would be" (teacher A, male)

According to the teachers, the initial stages of the project were also too demanding for elementary schools. In particular, they questioned whether students at this age are mature enough to discuss the global outreach of their community as was supposed they would do in stage 3:

"I was discomforted there was too much of these global outreaches, it fits rather to a secondary school. At the elementary school, I am happy if they get that something like a community exists and I would end it by this. For me, it is a great success if we get out of the school and then go to our local community." (teacher C, female)

"... my six graders do not speak about it (global outreach) and I think they are not mature enough for this" (teacher D, female)

Generally, the lack of time and energy for running a long program were repeatedly mentioned.

While teachers reported these difficulties, they also appreciated the importance of this part for dealing with the project successfully.

The students and the teachers mostly agreed in their interpretation of the process of cooperation as participative and democratic. A majority of the students believed that they had an opportunity to participate in the decision-making in all of the project stages (see Table 1):

Table 1. Students' perceived participation in the decision-making in the project.

\begin{tabular}{|c|c|c|c|c|c|}
\hline & $\begin{array}{c}\text { Totally } \\
\text { Agree (\%) }\end{array}$ & $\begin{array}{c}\text { Rather Agree } \\
(\%)\end{array}$ & $\begin{array}{c}\text { Not Sure } \\
(\%)\end{array}$ & $\begin{array}{c}\text { Rather } \\
\text { Disagree (\%) }\end{array}$ & $\begin{array}{c}\text { Totally } \\
\text { Disagree }(\%)\end{array}$ \\
\hline $\begin{array}{l}\text { In the project I could decide what tasks I would } \\
\text { participate in. }\end{array}$ & 24 & 39 & 20 & 11 & 5 \\
\hline $\begin{array}{c}\text { Every student had the right to suggest how to do } \\
\text { the agreed tasks. }\end{array}$ & 40 & 27 & 21 & 7 & 5 \\
\hline $\begin{array}{l}\text { Every student had the right to openly say their } \\
\text { opinion, even if the teachers disagreed with it. }\end{array}$ & 45 & 26 & 18 & 6 & 5 \\
\hline $\begin{array}{l}\text { We, as students, could promote our ideas, even if } \\
\text { our teachers did not like them at the beginning. }\end{array}$ & 31 & 33 & 17 & 11 & 8 \\
\hline $\begin{array}{l}\text { During planning, I could at any time suggest to } \\
\text { our teacher what we should deal with or what } \\
\text { problem to solve. }\end{array}$ & 23 & 29 & 27 & 16 & 5 \\
\hline
\end{tabular}

The teachers often reported their effort to give students enough freedom to make their own decisions and to speak their mind. The students described their teams as non-hierarchical ("as the round table of King Arthur") and they saw their teachers as guides or moderators:

"And our teacher was someone who was there, always ready to help you, and eventually she said her opinion but did not insist on it." (student A, female) 
The students highly appreciated the way in which their teams worked. They believed they cooperated in the spirit of mutual trust and support. At the same time, they could feel the lack of interest of the rest of their peers or colleagues. Due to this, the project remained a matter of small, isolated groups.

Surprisingly, while the students appreciated the democratic nature of their work in the AC program, their perception of the level of democracy in their school climate decreased significantly $\left(\mathrm{M}_{\text {before }}=17.66, \mathrm{SD}=4.19, \mathrm{M}_{\text {after }}=16.69, \mathrm{SD}=4.24, \mathrm{t}=2.81, p=0.006\right)$. The difference remained insignificant in the control group $\left(\mathrm{M}_{\mathrm{before}}=17, \mathrm{SD}=3.75, \mathrm{M}_{\mathrm{after}}=16.73, \mathrm{SD}=4.14, \mathrm{t}=0.45, p=0.654\right)$.

Self-efficacy in solving community-based problems significantly rose in the control group $\left(\mathrm{M}_{\text {before }}\right.$ $\left.=14.66, \mathrm{SD}=4.23, \mathrm{M}_{\mathrm{after}}=16.5, \mathrm{SD}=4.61, \mathrm{t}=-2.96, p=0.005\right)$ but not in the experimental group $\left(\mathrm{M}_{\text {before }}=16.26, \mathrm{SD}=4.43, \mathrm{M}_{\mathrm{after}}=17.05, \mathrm{SD}=4.12, \mathrm{t}=-1.83, p=0.13\right)$. This result, however, becomes the opposite once the effect of the students' gender is analyzed. The results for women were significantly higher in the post-test for both the experimental $\left(\mathrm{M}_{\mathrm{before}}=16.4, \mathrm{SD}=4.39, \mathrm{M}_{\mathrm{afte}} \mathrm{r}=\right.$ $17.84, \mathrm{SD}=3.65, \mathrm{t}=-2.2, p=0.033)$ and the control group $\left(\mathrm{M}_{\text {before }}=14.32, \mathrm{SD}=4.35, \mathrm{M}_{\mathrm{after}}=16.68\right.$, $\mathrm{SD}=4.07, \mathrm{t}=-2.56, p=0.02)$. The results for men rose significantly only in the control group $\left(\mathrm{M}_{\mathrm{before}}\right.$ $\left.=14.57, \mathrm{SD}=4.23, \mathrm{M}_{\mathrm{after}}=16.5, \mathrm{SD}=4.61, \mathrm{t}=-2.96, p=0.005\right)$ while they remained unchanged in the experimental group $\left(\mathrm{M}_{\text {before }}=16.26, \mathrm{SD}=4.43, \mathrm{M}_{\text {after }}=17.05, \mathrm{SD}=4.12, \mathrm{t}=-1.54, p=0.129\right)$.

The significant effect of gender was also found in the students' perception of their involvement in the planning and realization of the project after its completion $\left(\mathrm{M}_{\text {women }}=19.58, \mathrm{SD}=4.22, \mathrm{M}_{\operatorname{man}}=\right.$ $17.69, \mathrm{SD}=4.83, \mathrm{t}=2.4, p=0.018$ ).

In the interviews, the students repeatedly declared their belief that they could promote real change in their community. They were thankful for the opportunity to try something out and see the effect. This benefit of the AC program was appreciated also by the teachers.

"So, for me it was that even if we are young there's no need to underestimate us, and we rather can make a change despite our age, which is something that adults usually do not get very much, but we can see that it works." (student B, male)

"Yes, this is where I can see the change, these are the civic issues, this is how they could grow in front of our eyes. This is where I can see the biggest shift." (teacher B, female)

Another important motivational factor was the interest observed on the part of the local community after being informed about the students' plans. However, some of the students also had to face negative reactions from some of the local citizens.

Finally, while the respondents' reflection on the program may be considered a mixture of positive and negative feelings, overall, a positive view clearly prevailed:

"I think we have done a lot. We have made a castle from the sand. We just have done something and now, when we leave (the school), something we made remains here. And the younger (students) may continue... " (student $\mathrm{C}$, male)

\section{Discussion}

According to the qualitative findings, the AC program seems to have successfully developed students' intra- and interpersonal competence, namely their ability to cooperate and their sense of empowerment, due to their work in promoting real-world change.

However, in the light of the ambiguous findings in the quantitative part of the research, the impact of the program on students' self-efficacy seems less clear. It may be assumed that the program influenced some of the students, but not the majority. The issue of gender differences, i.e., educational programs' higher impact on girls compared with boys also has been found in other studies [51-54]; similar patterns were revealed in studies comparing the level of sustainability consciousness between boys and girls [55], while Goldman, Pe'er, and Yavetz [56] found these differences to be more complex. It could be assumed that the findings were affected by the low number of respondents in the control 
group, which has definitely been one of the limitations of the study. However, the lack of progress in self-efficacy for the participating boys may also indicate an existing limitation in the theory of the AC program.

As we have shown, the AC program implemented several generally recommended strategies. The program was conducted in a participative way and encouraged students to promote a real-world change in their local community $[11,12,17]$. Another interesting aspect was the meeting with members of the local community. This corresponds with the recommendation of Kahne and Westheimer [23] to provide meetings with active members of local communities and of Gaventa and Barett [20] to deal with a specific problem.

On the other hand, we can also see that, regarding the students' direct action, the projects tended to be rather non-controversial. While the reasons for such an approach may be considered obvious in a social environment where public involvement on the community level remains quite low, it may also be interpreted as one of the weaknesses of the AC program, compromising its educational impact on students $[24,25]$. While we do not have data to support this assumption, we assume that the participating teachers may have unintentionally framed the project selection process in such a way so as to avoid the students' choice of potentially controversial projects.

In the light of this, finding a way to promote teachers' acceptance of these kinds of projects could be one of the ways to enhance the AC program's effectiveness.

Another interesting aspect is the relative dissatisfaction with the initial stages of the program. This finding corresponds with that of Tejrovska [41], who reported that students often did not understand the meaning of these program activities, but they appreciated their importance after having finished their projects. In this context, we may ask if this strategy might offer a reasonable trade-off between keeping students' motivation and developing their intra- and interpersonal competencies. More generally, it opens up the question of how the intra- and interpersonal competencies, which are so important for successful involvement in a community-based project, should be developed: Should they be developed before or during the project?

The surprisingly negative impact of the project on the students' perception of their school culture can be easily interpreted as a result of two ongoing processes. The students deliberately chose to participate in a project whose level of expected democratic culture was likely to be in sharp contrast with their common school climate. The experience of "being the one sitting at King Arthur's table" could clearly demonstrate that a democratic culture of participation is possible while it is not practiced as a mainstream approach in schools. Furthermore, the lack of interest from other students might have increased the participants' feeling of isolation and exclusion. Both of these aspects might have led to the students' perceiving their school as a less favorable environment than before the program.

The analyzed program clearly demonstrated some of the important aspects of EEC, such as promotion of real-life change, involvement in community projects, and in some cases also community-based decision-making procedures. However, other features such as the addressing and questioning of the structural causes of environmental degradation and problems, the practice of environmental rights and duties, or the promotion of inter- and intra-generational justice were not presented in the AC program. It could be argued that by implementing some of these missing aspects, the program might increase not only its correspondence with EEC, but also and mainly its relevance for both students and local communities. To find the adequate, age-appropriate methods for this aim seems to be one of the challenges of contemporary education.

\section{Conclusions}

In the study we analyzed the Active Citizens program aiming to increase elementary school students' competence. While the program was evaluated positively by both students and teachers, we also uncovered some of its pitfalls, i.e., framing the process of project selection in favor of non-controversial activities and having unnecessarily long pre-project stages causing a decrease in the students' motivation. For the future implementation of similarly designed programs, we recommend 
focusing on the involvement of whole classes in some kind of cooperation on program activities, shortening the preparatory stages of the project, and encouraging teachers to support even the projects that are perceived by the community as controversial if such projects reflect the students' interests.

Author Contributions: Conceptualization, P.S. and J.C.; Methodology, P.S., J.C., and S.K.; Data Curation, P.S. and R.K.; Writing, J.C., P.S., A.H., and S.K.

Funding: The study was supported by the EU project "CIVIS-Focused on civic and social competence".

Acknowledgments: The international cooperation was further encouraged by our participation in the project European Network for Environmental Citizenship (COST Action 16229).

Conflicts of Interest: The authors declare no conflict of interest.

\section{References}

1. Hadjichambis, A.; Reis, P. European Network for Environmental Citizenship (ENEC). Impact 2018, 8, 52-54. [CrossRef]

2. Spektor-Levy, O.; Abramovich, A. From "Hesitant" to "Environmental Leader". The Influence of Professional Development Program on the Environmental Citizenship of Preschool Teachers. Eurasia J. Math. Sci. Technol. Educ. 2017, 13, 649-671. [CrossRef]

3. Ferreira, M.E.; Pitarma, R. Outdoor Learning Activities as Facilitators in the Construction of Environmental Citizenship in Advanced Learning and Teaching. In Environments-Innovation Contents and Methods; IntechOpen: Rijeka, Croatia, 2017.

4. Poudrier, C. Environmental education and active citizenship. J. Appl. Tech. Educ. Sci. 2017, 7, 31-36.

5. European Network for Environmental Citizenship-ENEC. Defining "Education for Environmental Citizenship". Available online: http://enec-cost.eu/our-approach/education-for-environmentalcitizenship/ (accessed on 23 November 2018).

6. Schild, R. Environmental citizenship: What can political theory contribute to environmental education practice? J. Environ. Educ. 2016, 47, 19-34. [CrossRef]

7. Smith, G.A. Place-based education: Breaking through the constraining regularities of public school. Environ. Educ. Res. 2007, 13, 189-207. [CrossRef]

8. Sobel, D. Place-Based Education: Connecting Classrooms \& Communities; The Orion Society: Barrington, IL, USA, 2005.

9. Stone, M.K.; Barlow, Z. Ecological Literacy. Educating Our Children for a Sustainable World; Sierra Club Books: San Francisco, CA, USA, 2005.

10. Gruenewald, D.A. The best of both worlds: A critical pedagogy of place. Environ. Educ. Res. 2008, 14, 308-324. [CrossRef]

11. Breiting, S.; Mogensen, F. Action Competence and Environmental Education. Camb. J. Educ. 1999, 29, 349-353. [CrossRef]

12. Jensen, B.B.; Schnack, K. The action competence approach in environmental education. Environ. Educ. Res. 1997, 3, 163-178. [CrossRef]

13. Barth, M.; Godemann, J.; Rieckmann, M.; Stoltenberg, U. Developing key competencies for sustainable development in higher education. Int. J. Sustain. High Educ. 2007, 8, 416-430. [CrossRef]

14. Rieckmann, M. Key competencies for a sustainable development of the world society. Results of a Delphi study in Europe and Latin America. GAIA-Ecol. Perspect. Sci. Soc. 2011, 20, 48-56.

15. Wiek, A.; Withycombe, L.; Redman, C.L. Key competencies in sustainability: A reference framework for academic program development. Sustain. Sci. 2011, 6, 203-218. [CrossRef]

16. Cincera, J.; Krajhanzl, J. Eco-Schools: What factors influence pupils' action competence for pro-environmental behaviour? J. Clean. Prod. 2013, 61, 117-121. [CrossRef]

17. Wals, A.E. Shaping the Education of Tomorrow: 2012 Full-Length Report on the UN Decade of Education for Sustainable Development. Unesco. 2012. Available online: http:/ / unesdoc.unesco.org/images/0021/ 002166/216606e.pdf102 (accessed on 1 December 2018).

18. Hoskins, B.; Kerr, D. Final Study Summary and Policy Recommendations Participatory Citizenship in the European Union; University of Southampton Education School: Southampton, UK, 2012. 
19. Kerr, D.; Sturman, L.; Schulz, W.; Burge, B. ICCS 2009 European Report. Civic Knowledge, Attitudes, and Engagement among Lower-Secondary Students in 24 European Countries; International Association for the Evaluation of Educational Achievement (IEA): Amsterdam, The Netherlands, 2010.

20. Gaventa, J.; Barrett, G. So what difference does it make? Mapping the outcomes of citizen engagement. IDS Work. Pap. 2010, 347, 1-72. [CrossRef]

21. Westheimer, J.; Kahne, J. What kind of citizen? The politics of educating for democracy. Am. Educ. Res. J. 2004, 41, 237-269. [CrossRef]

22. Cincera, J.; Kovacikova, S. Being an EcoTeam member: Movers and fighters. Appl. Environ. Educ. Commun. 2014, 13, 227-233. [CrossRef]

23. Kahne, J.; Westheimer, J. The limits of political efficacy: Educating citizens for a democratic society. Polit. Sci. Politics 2006, 39, 289-296. [CrossRef]

24. Boyte, H.C. Community Service and Civic Education. Phi Delta Kappan 1991, 72, 765-767.

25. Walker, T. The service/politics split: Rethinking service to teach political engagement. Polit. Sci. Politics 2000, 33, 647-649. [CrossRef]

26. Krajhanzl, J.; Chabada, T.; Svobodová, R. The Relationship of the Czech Public toward Nature and the Environment: Representative Public Opinion Surveys; Masaryk University: Brno, Czechoslovakia, 2018.

27. Petrova, T.; Tarrow, S. Transactional and participatory activism in the emerging European polity: The puzzle of East-Central Europe. Comp. Political Stud. 2007, 40, 74-94. [CrossRef]

28. Kroufek, R.; Janovec, J.; Chytrý, V. Pre-service primary teachers and their attitudes towards nature. In The Teaching Profession: New Challneges-New Identities; Lit Verlag GmbH \& Co. KG: Wien, Germany, 2015.

29. Kroufek, R.; Çelik, C.; Can, Ş. The Comparison of Environmental Literacy of Czech and Turkish Pre-Service Primary Teachers Using ELSA Scale. Turk. Online J. Educ. Technol. 2015, 8, 557-560.

30. Cincera, J.; Johnson, B. Earthkeepers in the Czech Republic: Experience from the implementation process of an earth education programme. Envigogika Charles Univ. E-J. Environ. Educ. 2013, 8. [CrossRef]

31. Van Petegem, P.; Blieck, A. The environmental worldview of children: A cross-cultural perspective. Environ. Educ. Res. 2015, 12, 625-635. [CrossRef]

32. Yilmaz, O.; Boone, W.J.; Andersen, H.O. Views of elementary and middle school Turkish students toward environmental issues. Int. J. Sci. Educ. 2004, 26, 1527-1546. [CrossRef]

33. Johnson, B.; Manoli, C.C. Using Bogner and Wiseman's Model of Ecological Values to measure the impact of an earth education programme on children's environmental perceptions. Environ. Educ. Res. 2008, 14, 115-127. [CrossRef]

34. Evans, G.W.; Juen, B.; Corral-Verdugo, V.; Corraliza, J.A.; Kaiser, F.G. Children's Cross-Cultural Environmental Attitudes and Self-Reported Behaviors. Child. Youth Environ. 2007, 17, 128-143.

35. Evans, G.W.; Brauchle, G.; Haq, A.; Stecker, R.; Wong, K.; Shapiro, E. Young children's environmental attitudes and behaviors. Environ. Behav. 2007, 39, 635-658. [CrossRef]

36. Şahin, H.; Erkal, S. The attitudes of middle school students towards the environment. Soc. Behav. Pers. Int. J. 2010, 38, 1061-1071. [CrossRef]

37. Cincera, J.; Jancarikova, K.; Matecek, T.; Simonova, P.; Bartos, J.; Lupac, M.; Broukalova, L. Environmental Education from Teachers' Perspective; Masaryk University: Brno, Czechoslovakia, 2016.

38. British Council: Active citizens. Available online: https://www.britishcouncil.org/active-citizens (accessed on 23 November 2018).

39. Endrstova, V.; Kubelkova, J.; Skalicka, P. Methodics of the Active Citizens Program; British Council, Man in Need, o. p. s.; Educational Program Variants: Prague, Czech Republic, 2014.

40. Active citizens. Available online: http:/ / www.activecitizens.cz (accessed on 23 November 2018).

41. Tejrovska, P.B. Anthropological Survey of Attitudes and Practice or Participants of the Active Citizens Program; Prague, Czech Republic, 2014. Available online: https://www.varianty.cz/download/docs/ 249_antropologicky-vyzkum-promen-postoju-a-praktik-ucastniku-programu-active-citizens.pdf (accessed on 1 May 2018).

42. American Educational Research Association; American Psychological Association; National Council on Measurement in Education. Standards for Educational and Psychological Testing; American Educational Research Association: Washington, DC, USA, 2014. 
43. Chen, G.; Gully, S.M.; Eden, D. Validation of a new general self-efficacy scale. Organ. Res. Methods 2001, 4, 62-83. [CrossRef]

44. Gastil, J.; Xenos, M. Of attitudes and engagement: Clarifying the reciprocal relationship between civic attitudes and political participation. J. Commun. 2010, 60, 318-343. [CrossRef]

45. Cincera, J.; Boeve-de Pauw, J.; Goldman, D.; Simonova, P. Emancipatory of instrumental? Students' and tachers' perception of the implementation of the EcoSchool program. Environ. Educ. Res. 2018. [CrossRef]

46. Vieno, A.; Perkins, D.D.; Smith, T.M.; Santinello, M. Democratic school climate and sense of community in school: A multilevel analysis. Am. J. Community Psychol. 2005, 36, 327-341. [CrossRef]

47. Rasch, D.; Guiard, V. The robustness of parametric statistical methods. Psychol. Sci. 2014, 46, 175-208.

48. Morgan, D.L. Focus Groups as Qualitative Research; Sage: Thousand Oaks, CA, USA, 1997.

49. Patton, M.Q. Qualitative Research and Evaluation Methods; Sage: Thousand Oaks, CA, USA, 2002.

50. Saldana, J. The Coding Manual for Qualitative Researchers; Sage: Thousand Oaks, CA, USA, 2015.

51. Boeve-de Pauw, J.; Van Petegem, P. The effect of eco-schools on children's environmental values and behaviour. J. Boil. Educ. 2013, 47, 96-103. [CrossRef]

52. Cincera, J.; Simonova, P. "I am not a big man": Evaluation of the issue investigation program. Appl. Environ. Educ. Commun. 2017, 16, 84-92. [CrossRef]

53. Cincera, J.; Skalik, J.; Binka, B. One world in schools: An evaluation of the human rights education programme in the Republic of Georgia. Camb. J. Educ. 2018, 1-18. [CrossRef]

54. Schumm, M.F.; Bogner, F.X. How Environmental Attitudes Interact with Cognitive Learning in a Science Lesson Module. Educ. Res. Int. 2016. [CrossRef]

55. Olsson, D.; Gericke, N. The effect of gender on students' sustainability consciousness: A nationwide Swedish study. J. Environ. Educ. 2017, 48, 357-370. [CrossRef]

56. Goldman, D.; Pe'er, S.; Yavetz, B. Environmental literacy of youth movement members-is environmentalism a component of their social activism? Environ. Educ. Res. 2017, 23, 486-514. [CrossRef]

(C) 2019 by the authors. Licensee MDPI, Basel, Switzerland. This article is an open access article distributed under the terms and conditions of the Creative Commons Attribution (CC BY) license (http:/ / creativecommons.org/licenses/by/4.0/). 